Part of Journal of Research of the National Bureau of Standards, Volume 36, May 1946

\title{
SIZE GRADING OF DIAMOND POWDER
}

\author{
By B. L. Steierman, H. Insiey, and W. H. Parsons
}

\section{ABSTRACT}

A study has been carried out on certain aspects of diamond-powder grading. Various liquids were tried as dispersing media, and of the 30 materials tested, gelatin solution was found to be the best. Several methods of separating the powder into size fractions were investigated and are discussed. The Cooke shortcolumn elutriator was found satisfactory for determining the size of large quantities of powder with little manual attention. Results of size fractionation are shown by photomicrographs.

\section{CONTENTS}

I. Introduction

II. Dispersing media_...

III. Methods of size separation

1. Sieving .

2. Sedimentation

(a) Direct settling

(b) Elutriation

IV. Discussion _.

V. Commercial standard and specification

VI. Summary _...

\section{INTRODUCTION}

Before 1940 the diamond dies for wire drawing used in this country were made abroad. After the manufacture of diamond dies was begun in this country, it became evident that the domestic supply of diamond powder used for drilling these dies was not of proper quality. The present project was undertaken with three general aims: first, to determine the efficiency of various methods for separating diamond powder into size fractions; second, to determine the best dispersants for diamond powder; and third, to obtain data suitable for a basis for writing a standard covering the size and grading of diamond powder for commercial producers and users. It is also believed that the results may be of use in the sizing and grading of powders other than diamond.

\section{DISPENSING MEDIA}

For any method of sedimenting, elutriating, or examining diamond powder in a liquid, a suitable dispersing agent is necessary. In order 
to be effective as a dispersant, a liquid must be able to wet diamond and to develop an electric charge on the particles. If the liquid does not wet the diamond particles, agglomeration will not be overcome, because of surface tension of the liquid. Furthermore, it is apparent that if the particles are neutral electrically, there will be no repulsive effect between particles. However, particles having like charges will repel each other, and hence will not tend to aggregate.

The wetting power of a liquid with respect to diamond was determined by mixing a small quantity of liquid and diamond powder on a glass slide. If the liquid flowed over the powder and enveloped it, that particular liquid was judged to wet diamond. On the other hand, if the liquid pushed the powder away it did not wet diamond.

A small electrophoresis cell was used for determining the kind of charge developed on diamond when in contact with a liquid. This cell was a glass microscope slide with two aluminum electrodes cemented to it about $1 \mathrm{~mm}$ apart. A drop of liquid with added diamond powder was placed on the slide and covered with a cover glass. Leads from a 110-volt direct-current line were connected to the electrodes. The cell was placed under a microscope, and the movement of the particles was observed. If the particles moved toward the positive electrode, the charge of the particle was negative. Diamond developed a negative electric charge in contact with all the liquids tried.

The method used in determining the degree of dispersion was examination by dark and bright field illumination. The liquid to be tested was mixed with a small quantity of fine (approximately 1 micron) diamond powder in a vial or on a microscope slide and then examined microscopically. The presence or absence of aggregates, separation of the particles, and Brownian movement were observed, and a rating of excellent, good, fair, or poor was given. Due regard was taken of the effect of viscosity on the Brownian movement. Table 1 shows the relation of the rating to the appearance of the powder under the microscope. The results of the dispersing tests are given in table 2.

TABLE 1.-Relation of rating to appearance of the powder under the microscope

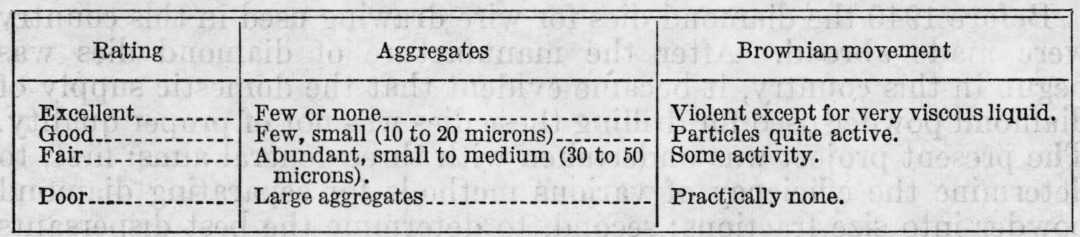

After testing the liquids (see table 2), the solution of gelatin in water was selected as best suited for a suspending medium for sedimentation. This solution contains between 0.1 and 0.25 percent of gelatin, with sodium carbonate added to give a $\mathrm{pH}$ of 9 . A few drops of thymol were added to prevent the growth of fungi or bacteria. The gelatin solution besides giving good dispersion has the added advantage of a viscosity approximately as low as water. This results in giving sedimentation velocities that are relatively high, much higher than if more viscous liquids, such as pine or olive oil, were 
used. Comparison with pine oil, alcohol, ethylene glycol, and other liquids indicates that the gelatin solution is also the cheapest and most easily procured dispersant.

TABLE 2.-Dispersive power of liquids

\begin{tabular}{|c|c|c|}
\hline Liquid & Dispersive power & Remarks \\
\hline Triethanolamine & Fair & \multirow{3}{*}{$\begin{array}{l}\text { No Brownian movement; viscous, } \\
\text { toxic, expensive. } \\
\text { Too volatile. } \\
\text { Extreme aggregation. }\end{array}$} \\
\hline Hexaldehyde... & Good.. & \\
\hline $\begin{array}{l}\text { Flexol } \\
\text { Kapsol (methoxyethyloleat }\end{array}$ & Poor & \\
\hline Butoxy ethyl stearate......... & Fair & \multirow{4}{*}{$\begin{array}{l}\text { Expensive. } \\
\text { Very viscous. } \\
\text { Do. }\end{array}$} \\
\hline $\begin{array}{l}\text { Methylcellosolve... } \\
\text { Glycol sebacate.... }\end{array}$ & Good... & \\
\hline Machine oil & Poor-- & \\
\hline $\begin{array}{l}\text { Transformer oil. } \\
\text { Octoil }\end{array}$ & Fair & \\
\hline Ethyl alcohol & Poor & \multirow{3}{*}{$\begin{array}{l}\text { Too volatile, bad aggregation. } \\
\text { Does not wet diamond. }\end{array}$} \\
\hline $\begin{array}{l}\text { 1-percent calgon in water } \\
\text { Kerosine.... }\end{array}$ & Fair & \\
\hline 1 percent oleic acid in kerosine & do & \\
\hline $\begin{array}{l}\text { Oleic acid. } \\
\text { Olive oil }\end{array}$ & Good & \multirow{5}{*}{$\begin{array}{l}\text { Viscous and expensive. } \\
\text { Too viscous. } \\
\text { Do. } \\
\text { Do. }\end{array}$} \\
\hline $\begin{array}{l}\text { Ethylene glycol } \\
\text { Mineral oil }\end{array}$ & Fair & \\
\hline Castor oil & do & \\
\hline Glycerine & Poor & \\
\hline 1 percent aerosol in water..... & & \\
\hline $\begin{array}{l}0.1 \text { to } 0.25 \text { percent gelatin solution in } \\
\text { water. }\end{array}$ & $\begin{array}{l}\text { Good, excellent.-. } \\
\text { Excellent........... }\end{array}$ & \multirow{5}{*}{$\begin{array}{l}\text { Series of oils in various viscosities. } \\
\mathrm{Na}_{2} \mathrm{CO}_{3} \text { to give pH of } 9 \text {. Thymol } \\
\text { as germicide. } \\
\text { Too viscous. } \\
\text { Viscous, used for photomicrographs. } \\
\text { Solid at room temperature. }\end{array}$} \\
\hline $\begin{array}{l}\text { Diamond drill oil } \\
\text { Bayol } \\
\text { Fractol AA }\end{array}$ & Good & \\
\hline $\begin{array}{l}0.2 \text { percent calcium lignin sulfonate } \\
\text { in water. }\end{array}$ & & \\
\hline $\begin{array}{l}\text { Canada balsam } \\
\text { Hyrax }\end{array}$ & Excellent & \\
\hline & & \\
\hline
\end{tabular}

\section{METHODS OF SIZE SEPARATION}

\section{SIEVING}

Only a comparatively small amount of time was devoted to a study of sieving because the subject has been treated at length in the literature on grinding, milling, and particle-size analysis and also because the present investigation was mainly concerned with diamond powder of subsieve sizes.

The diamond crystals were crushed in a diamond mortar and sieved dry. Four sieves (diameter 3 inches) were used in a stacked arrangement-U. S. Standard Sieve Nos. 170, 200, 275, and 325. The sieving was done by hand, combining rotary and sidewise shaking with tapping, perpendicular to the sieve.

Microscopic examination of the sieved fraction showed considerable amounts of very fine particles to be present. These particles adhered to the surfaces of the larger grains. In order to remove these fine particles, the powder retained on a No. 325 sieve was poured into a beaker of acetone, stirred vigorously, quickly sedimented, and the fines still in suspension were poured off. This process was repeated several times. Then the sedimented powder was washed with acetone and dried. The supernatant acetone containing the fines was evaporated, and the fine particles were added to the less than 
No. 325 sieve fraction. Sieving, as here described, gave very uniform results. The particle-size range was narrow. Micrographs of two fractions are shown in figures 1 and 2.

\section{SEDIMENTATION}

In order to use any settling method it is necessary to calculate a table of settling velocities. The calculations are based on Stokes' law:

where

$$
V=(2 / 9) g a^{2}\left(D_{1}-D_{2}\right) 1 / \eta,
$$

$V=$ sedimentation velocity, $\mathrm{cm} / \mathrm{sec}$

$g=980 \mathrm{~cm} / \mathrm{sec}^{2}$

$a=$ radius of particles

$D_{1}=$ density of diamond, 3.52

$D_{2}=$ density of gelatin solution, 0.99

$\eta=$ coefficient of viscosity, poises.

This equation can be simplified as follows:

where

$$
V=a^{2} K \text {, }
$$

$$
\begin{aligned}
K & =551 \theta \\
\theta & =\text { fluidity of gelatin solution, } 1 / \eta \\
V & =(2,9) 980(3.52-.99) a^{2} 1 / \eta \\
V & =551 a^{2} \theta
\end{aligned}
$$

Table 3 gives the values of $K$ and $\theta$ for various temperatures, based

\begin{tabular}{|c|c|c|c|}
\hline$T$ & \multicolumn{2}{|c|}{$K$} & $\theta$ \\
\hline $\begin{array}{l}{ }^{\circ} \mathrm{C} \\
15 \\
17.5 \\
20.0 \\
22.5 \\
23.0 \\
25\end{array}$ & \multicolumn{2}{|c|}{$\begin{array}{l}48,300 \\
51,335 \\
54,800 \\
58,220 \\
58,890 \\
61,610\end{array}$} & $\begin{array}{r}87.69 \\
93.53 \\
99.50 \\
105.63 \\
106.86 \\
111.91\end{array}$ \\
\hline \multicolumn{4}{|c|}{ DIAMETERS AND RADII OF PARTICLES } \\
\hline Diameter & Radius & $a$ & $a^{2}$ \\
\hline $\begin{array}{c}\text { Microns } \\
2 \\
5 \\
8 \\
10 \\
15 \\
25 \\
35 \\
55 \\
70 \\
85 \\
120\end{array}$ & $\begin{array}{c}c m \\
0.00010 \\
.00025 \\
.00040 \\
.00050 \\
.00075 \\
.00125 \\
.00175 \\
.00275 \\
.00350 \\
.00425 \\
.00600\end{array}$ & $\begin{array}{c}c m \times 10^{-5} \\
10 \\
25 \\
40 \\
50 \\
75 \\
125 \\
175 \\
275 \\
350 \\
425 \\
600\end{array}$ & $\begin{array}{c}c m \times 10^{-10} \\
100 \\
625 \\
1,600 \\
2,500 \\
5,625 \\
15,625 \\
30,625 \\
75,625 \\
122,500 \\
180,625 \\
360,000\end{array}$ \\
\hline
\end{tabular}
on the use of gelatin solution, also a table of diameters and radii of particles. Table 4 gives the sedimentation rates for diamonds of various sizes and grades.

TABLE 3.-Factors used to determine settling rates of diamond powder in gelatin solution 


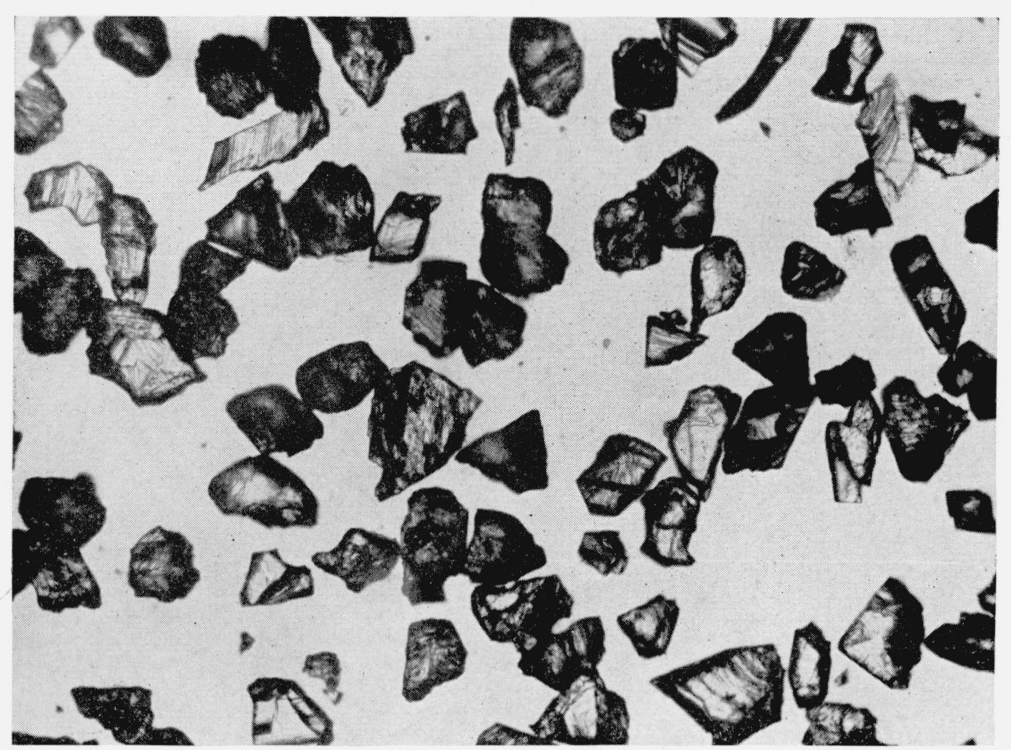

FIGURE 1.-Sieved fraction of diamond powder through No. 200 sieve and retained on No. 270.

Magnification, $\times 200$.

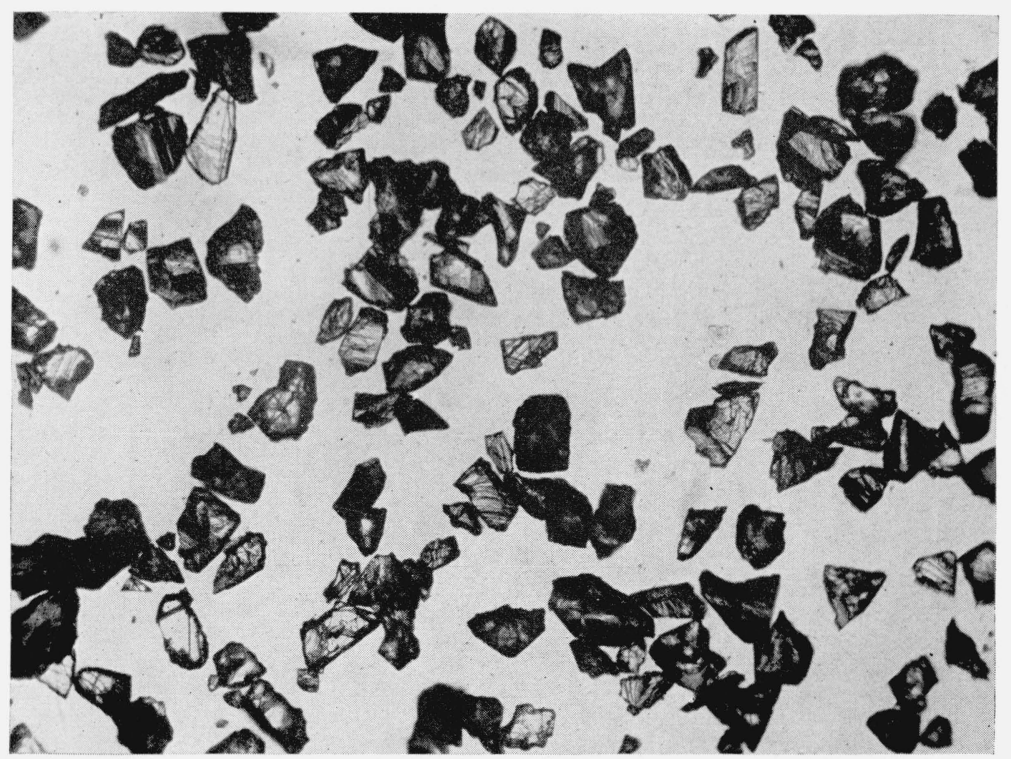

FIGURE 2.- Sieved fraction of diamond powder through No. 27O sieve and retained on No. 325 . 


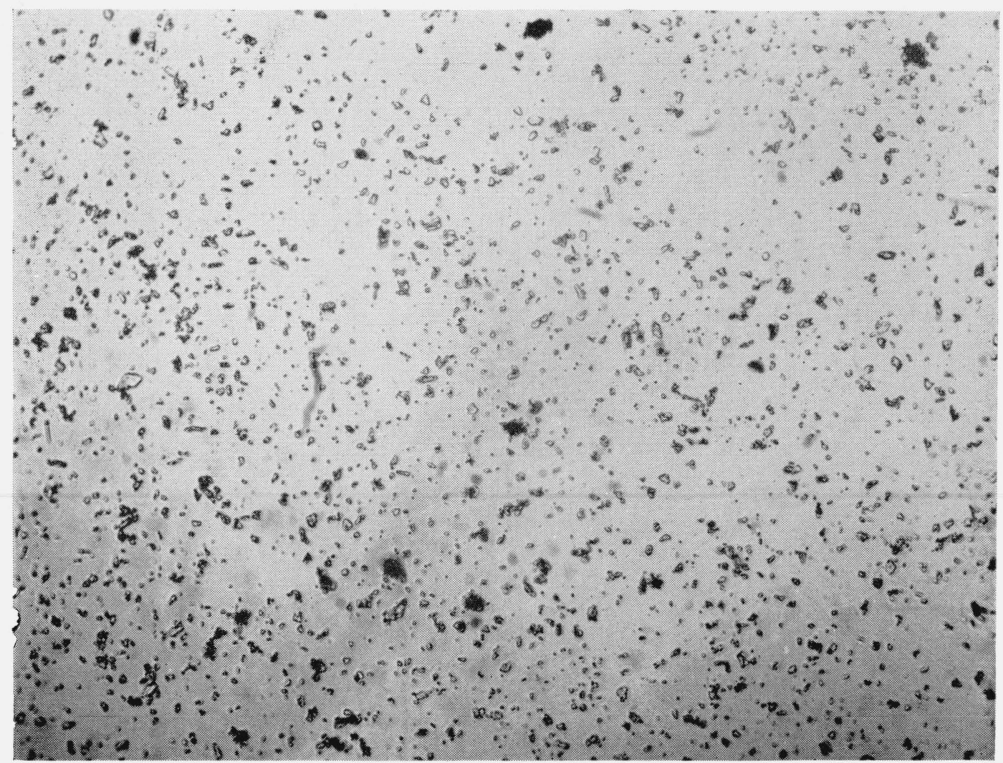

FigURE 3.-Diamond powder fraction by settling, average size 1.5 microns. Magnification, $\times 400$

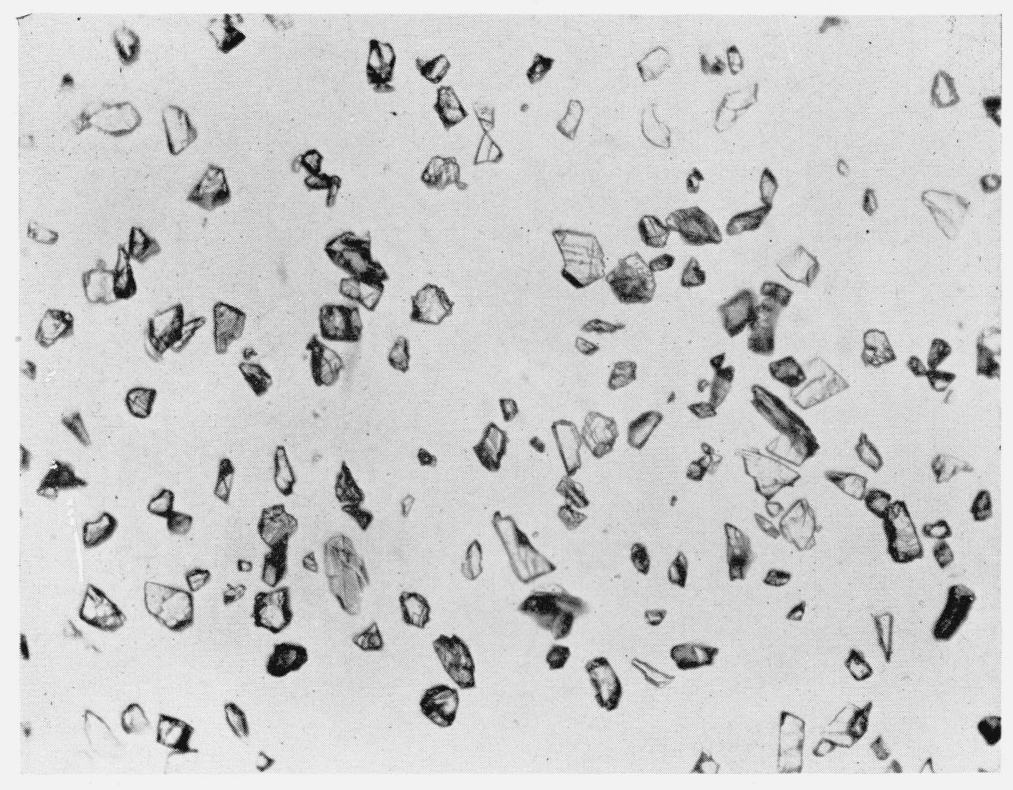

FiguRE 4.-Diamond powder fraction by settling, average size 7 microns. Magnification, $\times 400$. 
TABLE 4.-Sedimentation rates for diamond in gelatin solution

[Temperature, $25^{\circ} \mathrm{C}$, when $V=a^{2} 61,610$ ]

\begin{tabular}{|c|c|c|c|c|c|c|c|c|}
\hline Grade designation & $\begin{array}{l}\text { Maxi- } \\
\text { mum } \\
\text { size of } \\
\text { diamond } \\
\text { particle }\end{array}$ & $a^{2}$ & $V$ & $1 / V$ & $5 / V$ & Time rec & quired to se & $5 \mathrm{~cm}$ \\
\hline 60 & $\begin{array}{r}\text { Microns } \\
2 \\
5 \\
8 \\
10 \\
20 \\
37 \\
60 \\
85 \\
120\end{array}$ & $\begin{array}{r}c m \times 10^{-10} \\
100 \\
625 \\
1,600 \\
2,500 \\
10,000 \\
34,225 \\
90,000 \\
180,625 \\
360,000\end{array}$ & $\begin{array}{c}\mathrm{cm} / \mathrm{sec} \\
0.0006 \\
.0039 \\
.0099 \\
.0154 \\
.0616 \\
.2107 \\
.5545 \\
1.114 \\
2.220\end{array}$ & $\begin{array}{r}\mathrm{sec} / \mathrm{cm} \\
1,666 \\
256 \\
101 \\
64.9 \\
16.2 \\
4.7 \\
1.8 \\
\end{array}$ & $\begin{array}{r}\mathrm{sec} / 5 \mathrm{~cm} \\
8,330 \\
1,280 \\
505 \\
324 \\
81 \\
24 \\
9 \\
5 \\
2\end{array}$ & $\begin{array}{c}{ }^{2} h r \\
\end{array}$ & $\begin{array}{r}{ }_{18} \\
18 \\
21 \\
8 \\
5 \\
1 \\
\\
\\
\end{array}$ & sec \\
\hline
\end{tabular}

(a) DIRECT SETTLING

Some tests were performed to determine the efficiency of direct settling as a method of size separation of diamond powder. The diamond powder was mixed with a small quantity of the gelatin solution prepared as mentioned in section II and stirred for one-half hour with an electric mixer. The suspension was diluted to a volume of 2 liters and placed in an asbestos-jacketed enamel can about $12 \mathrm{~cm}$ in diameter. The asbestos lagging was used to prevent radiation losses and to reduce convection currents.

After the stirring, the suspension was allowed to settle for a length of time such that all particles greater in size than the finest desired fraction had settled $5 \mathrm{~cm}$. The upper liquid was then drawn off. A rack was constructed so that it could be used to set a pipette to remove liquid to a predetermined depth. The tip of the pipette was bent at right angles to its length so as not to withdraw material that had settled below the desired depth. This sedimentation was repeated several times, each time making the suspension up to the original volume, and again stirring and settling before removing a fraction. The withdrawals were all combined as the finest fraction and concentrated by centrifuging.

The above procedure was then repeated for coarser fractions at a different settling time. The fractions produced in this way are shown in figures 3 and 4. As can be seen from these photomicrographs, the size grading of the powder is fairly good. Average sizes are 1.5 and 7 microns in the size ranges 0 to 3 and 3 to 10 microns, respectively. If more sedimentations had been made of each size fraction, a clearer, sharper separation might have resulted.

The number of sedimentations necessary to give a required degree of separation can be easily calculated. If 30 percent of the material of a given size is removed each time, then 70 percent will remain. The next sedimentation will remove 30 percent of the remaining 70 percent, or 21 percent of the original, and so on. This will be found to require eight sedimentations to remove 94.2 percent, or six sedimentations to remove 88 percent. 


\section{(b) ELUTRIATION}

Size separations were made with the Cooke elutriator. ${ }^{1}$ The apparatus built for the present research was modeled after the original Cooke apparatus, with some slight modification to meet the

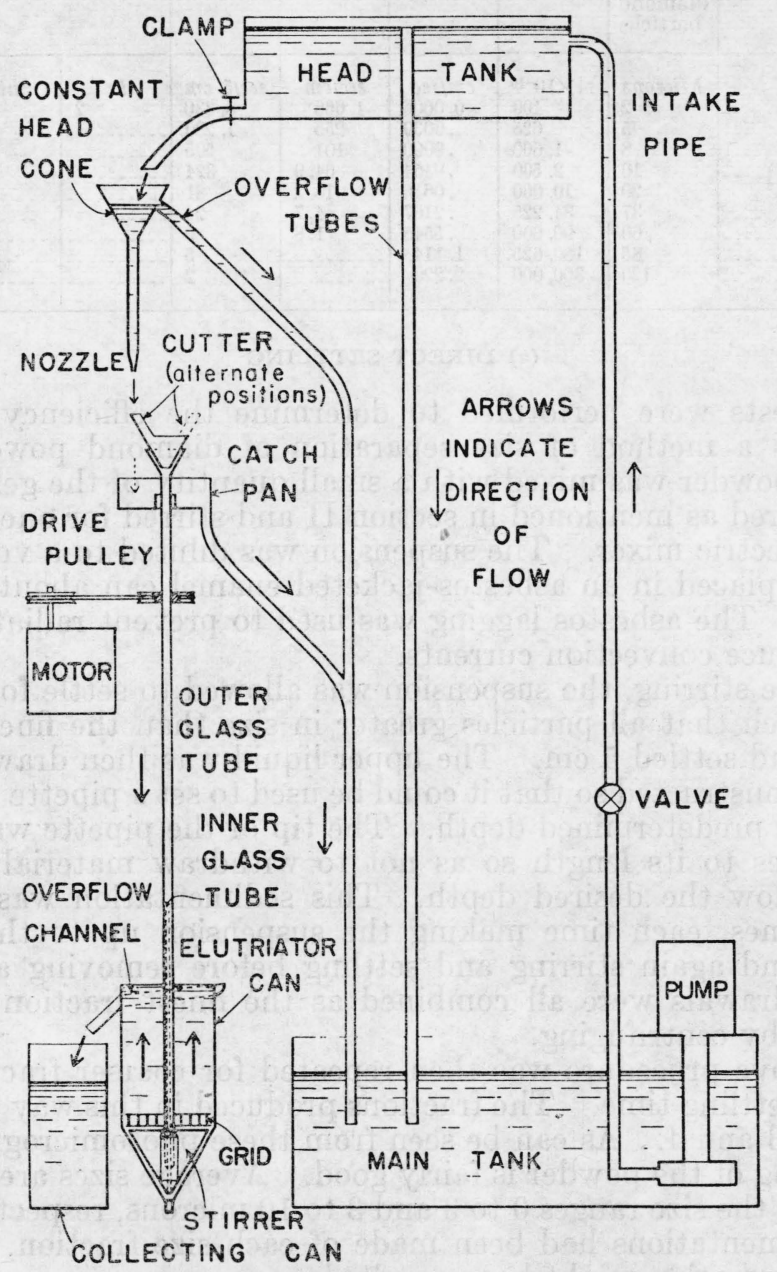

FIgURE 5.-Diagram of Cooke elutriator.

conditions in the constant-temperature room. A 0.1-percent-gelatin solution, made as indicated in section II, was used.

Figure 5 is a diagram of the main elements; some of the parts are shown in figure 6 . The stirrer blade is shown in figures 5 and 6 at the lower end of the glass tubes. It consists of two perforated metal vanes. Above this is a metal grid, and both elements are surrounded by the elutriator can.

${ }^{1}$ S. R. B. Cooke, A new short column hydraulic elutriator, U. S. Bureau of Mines Report of Investigation No. 3333 (1937). 

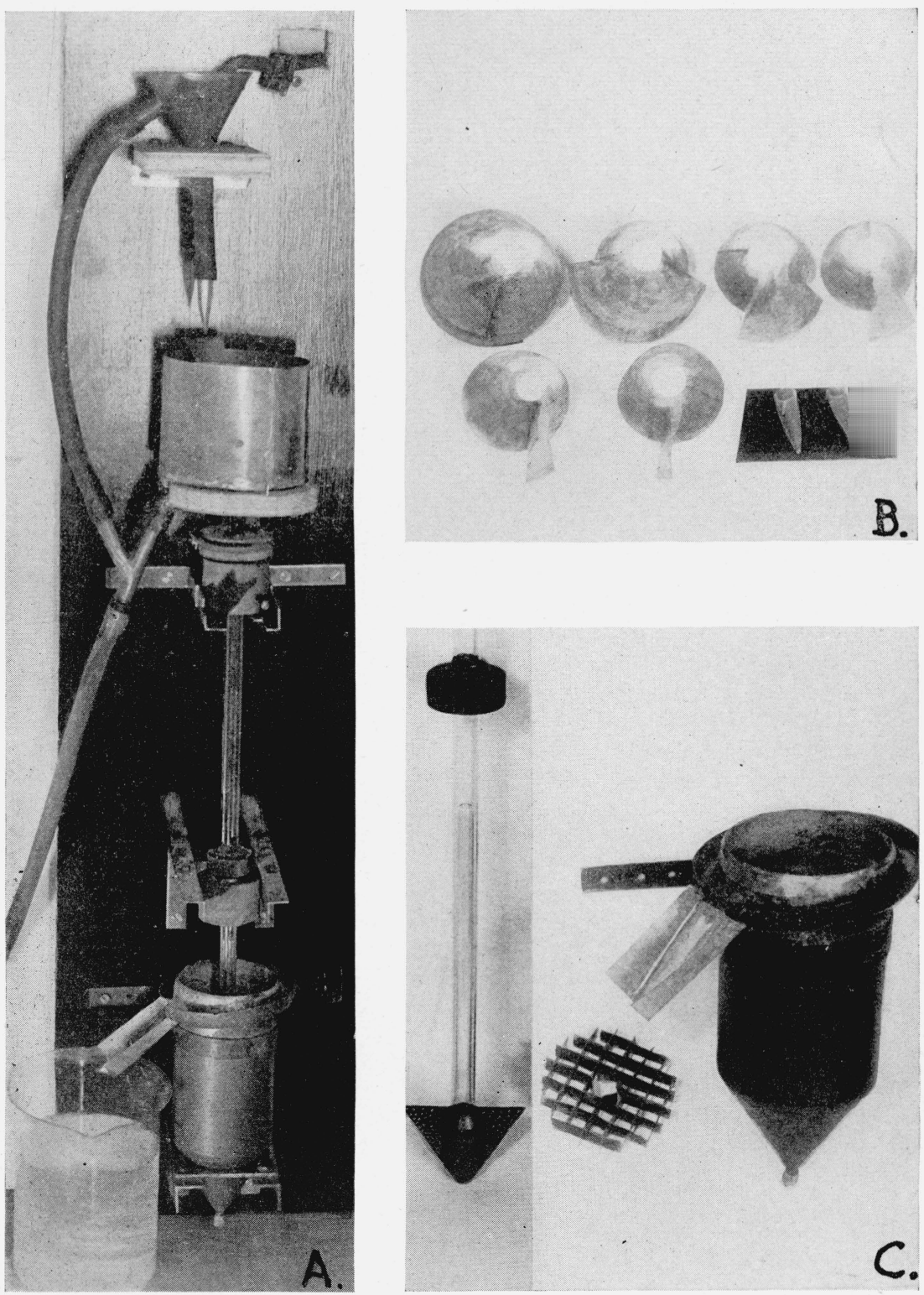

FIgURE 6.-Cooke elutriator and parts.

$A$, Assembled elutriator; $B$, the 6 cutters $(360,180,90,45,221 / 2$, and $111 / 4$ degrees) and 2 nozzles; $C$ (left to right), glass tubes with stirrer, grid, and elutriator can with overflow channel. 


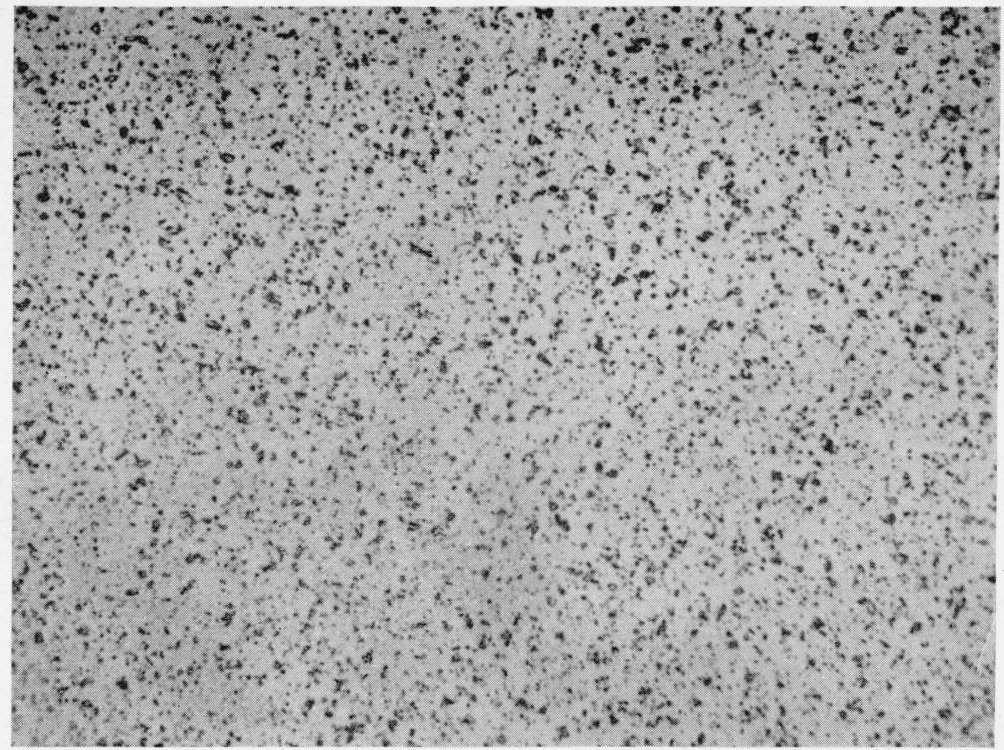

FIGURE 7.-Elutriated diamond powder fraction, average size 1 micron.

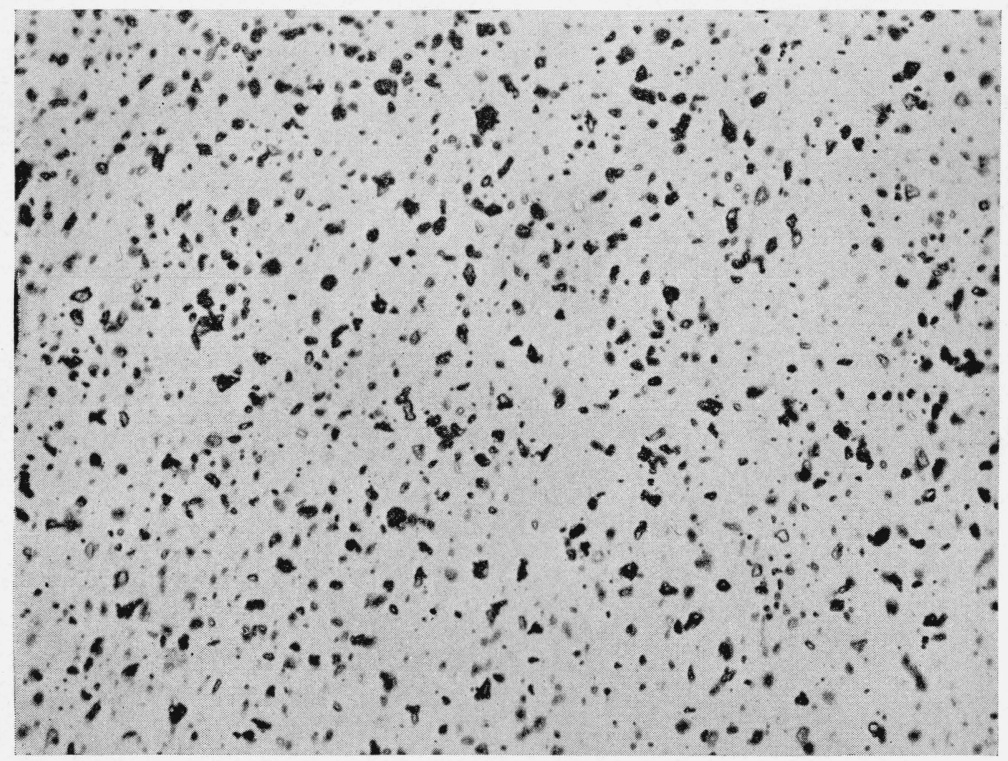

FIGURE 8.-Elutriated diamond powder fraction, average size 2 microns. Magnification, $\times 400$. 


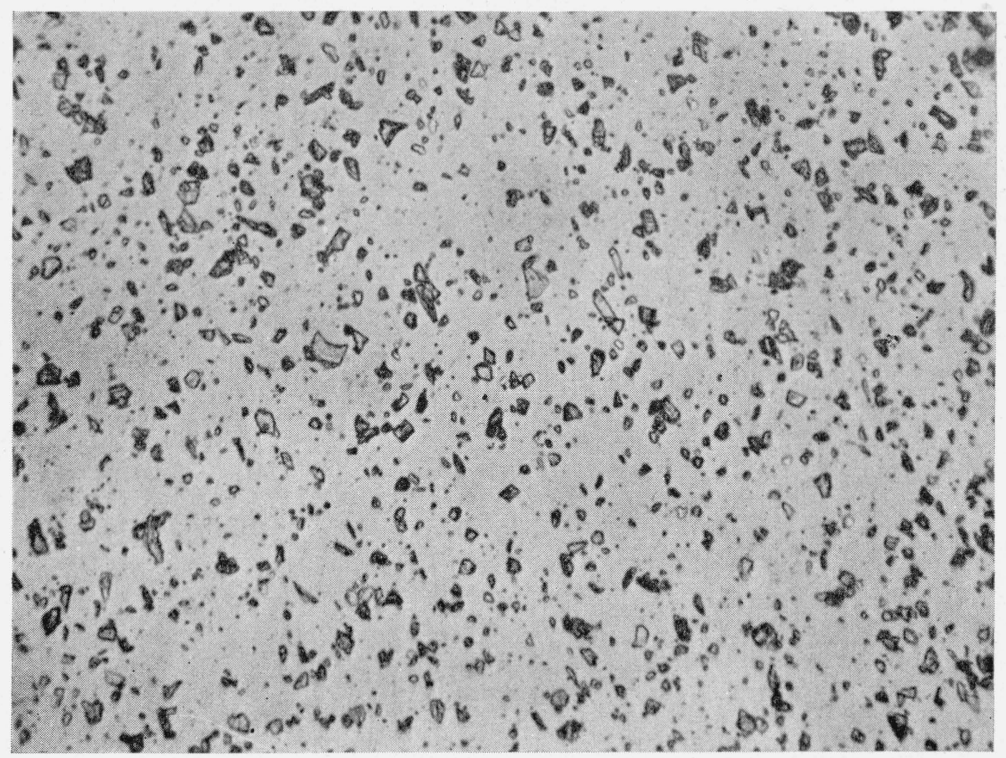

FIGURE 9.-Elutriated diamond powder fraction, average size 5 microns. Magnification, $\times 400$. 
Operation of the machine is quite simple. A slurry of diamond powder and gelatin solution is introduced into the open top of the elutriator can. Gelatin solution flows down an outer glass tube and overflows into an inner glass tube to enter the elutriator can at its lower end, flows up and over the lip of the can into the overflow channel, then into a collecting can. Arrows in the diagram indicate the direction of flow. The rate of upward flow of liquid determines the grain size washed over the lip of the can.

In order to obtain a definite rate of flow, a constant head cone, cutter, and nozzle are necessary. The constant head cone provides the nozzle with a stream of liquid under constant pressure. The nozzle is so made as to deliver a definite volume of liquid per minute. As the fine sizes require flow rates of very small magnitude, a system of cutters is employed. These cutters are sectors of cones made of metal or celluloid. When the glass tube revolves at a constant rate (about $25 \mathrm{rpm}$ ), the cutter takes a definite portion of the stream from the nozzle, the remainder flowing back into the main tank. Cutters are of various sizes, 360 degrees for all the flow, 180 degrees for half the flow, etc.

By careful choice of nozzle and cutter any upward rate of flow may be obtained. For example, if the upward rate of flow just exceeds the sedimentation velocity for a 1-micron particle of diamond, then all particles 1 micron or smaller will overflow and be recovered in the collecting can. This overflow process is continued until examination of the overflow shows that no more particles 1 micron or smaller remain in the elutriator. The cutter can then be changed for a larger one to produce a greater flow such that the next desired size fraction is removed.

The stirrer is used to agitate the diamond slurry and prevent aggregation. In order to prevent turbulent effects caused by the rotation of the stirrer blade, a grid is used. This grid prevents any rotary motion of liquid in the upper part of the can and forces the liquid to rise vertically.

The diamond powder is then removed from the gelatin solution by the following method. For coarser sizes of powder (down to 15 to 20 microns) large volumes of liquid are encountered, and the separation takes place in two steps. First, the suspension is allowed to stand for a day, which brings the powder down to the bottom of a container about 10 inches deep. The excess liquid is decanted. Second, the slurry at the bottom is evaporated or centrifuged to remove the remaining water. After this, the powder is cleaned with hydrofluoric, nitric, and sulfuric acids in a platinum dish.

For the finer fractions, the volume of liquid from the elutriator is seldom more than a few liters. In this case, the liquid is separated by centrifuging and decantation of the supernatant liquid. The powder is collected, the excess liquid is evaporated, and the powder subjected to the cleaning process.

For a larger installation on a commercial scale it might be desirable to use a basket type or a continuous centrifuge. The cleaning in that case could be done with hot hydrochloric acid and hot dichromatesulfuric acid cleaning solutions, followed by rinsing, filtration, and final ignition. 
As diamond powder is relatively expensive, preliminary test runs in the elutriator were made with fluorite, which is quite similar to diamond in some of its physical properties. Both are cubic, with good octahedral cleavage, have similar densities (3.25 and 3.5), and have the same electric charge in water.

With fluorite, fractions were produced with uniform grain size. Four fractions were made, 0 to $2.5,2.5$ to 5,5 to 7.5 , and 7.5 to 10 microns. The average sizes, determined microscopically, of the fractions were $2,5,7$, and 9 microns.

A charge of diamond powder was next used. Six fractions and a residue in the elutriator were recovered. Three of these fractions are shown in figures 7,8 , and 9 . The size ranges (in microns) are 0 to 2,1 to 3 , and 2 to 7 . Average sizes for these grades are 1,2, and 5 microns.

There are several reasons to account for the better uniformity of the size grading of fluorite as compared to the diamond powders. The fluorite fractions were made continuously, whereas when running the diamond powder several shutdowns of the machine were necessary. The lack of reservoir capacity for the gelatin solution prevented overnight operation and, therefore, the machine was shut down at night. However, in a commercial installation enough fluid capacity could be made available so as to avoid the necessity of fairly constant attendance in order to maintain the supply of elutriator fluid. As a result of these shutdowns there was some flocculation of the diamond powder. Also it is believed that the diamond powder requires longer and more intense stirring to break up aggregations.

\section{DISCUSSION}

Other methods that might be used for the size grading of diamond powders include the British centrifuge method and air elutriation.

The first of these methods is described in a British report. ${ }^{2}$ No work was done at the Bureau in sizing powder by this method, but the powders so produced have been examined and found to be quite uniform in size. Between 1939 and 1941 they were the best to be had in this country. For large-scale production the method is believed to have certain disadvantages - the time required for centrifuging under constant attention of an operator tends to make the process uneconomical. There is often difficulty in controling the time of centrifuging, especially for larger sizes. The equipment and supplies are relatively expensive. On the other hand, this is a simple process that does good grading.

The air elutriator offers no distinct advantages over the liquid apparatus, except that the finished product requires no cleaning. However, air elutriation equipment is commercially available and has been used on diamond powder and other products. ${ }^{34}$ It was not tried

\footnotetext{
2 Report 7821, Research Laboratories of the General Electric Co., Ltd. (1941).

3 P. S. Roller and P.V. Roundy, Jr., Surface area of portland Cement-Symposium on new methods for particle size determination in the subsieve range. Am. Soc. Testing Materials (1941).

4 P. S. Roller, Measurement of particle size with an acurate air analyser, Proc. Am. Soc. Testing Materials 32, pt. II, 607 (1932).
} 
in this investigation because the equipment was not available at the time.

This work has indicated that the Cooke elutriator is very well suited for the size grading of diamond powder. It requires little attention as compared to other methods.

Probably the most economical way to operate the Cooke machine commercially would be in the form of a battery of five or more in parallel. If the tanks were sufficiently large, it is evident that one head tank and one main tank and pump could serve several elutriators. Also one motor and one speed reducer could drive the stirrers and cutters of several machines. One large tank could receive the overflow from several machines.

The attention required by a battery of elutriators would be little more than that for a single one. It was found that about 15 minutes would be required to change cutters and receptacles for each fraction for a battery of five elutriators. Loading would take about 5 minutes to a machine, and cleaning out each machine after the last fraction has been made would take about 5 minutes.

\section{COMMERCIAL STANDARD AND SPECIFICATION}

As a result of a part of this work, a Commercial Standard ${ }^{5}$ was devised by the Bureau's Division of Trade Standards. By conference with producers and consumers, this was adjusted to meet the requirements of the trade and was finally adopted on March 6, 1945. The sizes and grades as given in that standard are shown in table 5 .

TABLE 5.-Grade designation, grain size, and sieve numbers

\begin{tabular}{|c|c|c|c|}
\hline \multirow{2}{*}{$\begin{array}{l}\text { Grade desig- } \\
\text { nation }^{1}\end{array}$} & \multicolumn{2}{|c|}{ Grain size (microns) } & \multirow{2}{*}{$\begin{array}{l}\text { U. S. Stand- } \\
\text { ard Sieve } \\
\text { number } \\
\text { (through) }{ }^{2}\end{array}$} \\
\hline & Minimum & Maximum & \\
\hline $\begin{array}{l}1 \\
2 \\
3 \\
3 \mathrm{X} \\
6\end{array}$ & $\begin{array}{l}0 \\
1 \\
1 \\
0 \\
4\end{array}$ & $\begin{array}{l}2 \\
3 \\
5 \\
6 \\
8\end{array}$ & 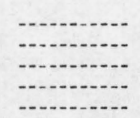 \\
\hline $\begin{array}{l}8 \\
8 X \\
14 \\
25 \\
40\end{array}$ & $\begin{array}{r}6 \\
4 \\
8 \\
13 \\
20\end{array}$ & $\begin{array}{l}10 \\
12 \\
20 \\
37 \\
60\end{array}$ & 325 \\
\hline $\begin{array}{r}60 \\
90 \\
120 \\
150 \\
180\end{array}$ & $\begin{array}{r}35 \\
60 \\
80 \\
100 \\
120\end{array}$ & $\begin{array}{r}85 \\
120 \\
160 \\
200 \\
240\end{array}$ & $\begin{array}{r}230 \\
170 \\
120 \\
100 \\
80\end{array}$ \\
\hline $\begin{array}{l}250 \\
400\end{array}$ & $\begin{array}{l}150 \\
250\end{array}$ & $\begin{array}{l}350 \\
550\end{array}$ & $\begin{array}{l}60 \\
40\end{array}$ \\
\hline
\end{tabular}

1 Grades 1, 6, and 8 are narrow-range grades for exacting work in cutting and polishing fine diamond dies, sapphire bearings, etc. Grades $3 \mathrm{X}$ and $8 \mathrm{X}$ are wide-range grades desired for some purposes.

2 United States Standard Sieve series. Sieve numbers are included for reference only. It does not necessarily follow that powders passing the sieve indicated for a grade will meet the grain-size requirements of that grade, nor that powders retained on the sieve necessarily fail to meet the grain-size requirements.

${ }^{8}$ Commercial Standard CS123-45, Grading of diamond powder (1945). 


\section{SUMMARY}

Dilute gelatin solution was the best liquid of the 30 tried for dispersing and sedimenting diamond powder.

Sieving was found to give a clean separation of the larger size fractions if the coarse fraction was washed in acetone after the sieving.

Direct settling gave size separation that was fairly good.

The Cooke elutriator was found to be the most economical of the methods tried for the size grading of diamond powder.

This work was instigated and financed by the War Production Board and the War Metallurgy Committee of the National Academy of Sciences. The study was first published as War Production Board Serial No. W-156.

Washington, January 31, 1946. 